\title{
"THE INFINITE POEM IN PROGRESS": LOUIS DUDEK'S LONG POEMS ${ }^{1}$
}

\author{
ANTONIO RUIZ SÁNCHEZ \\ Universidad de Córdoba
}

A look at the numerous attempts to define the Canadian long poem will reveal the role this poetic genre has played in the development of Canadian poetry. Already in 1946, Northrop Frye observed that: "[i]n looking over the best poems of our best poets (...) we are surprised to find how often the narrative poem has been attempted, and attempted with uneven but frequently remarkable success" (Frye, 1971:149). A few years later, Milton Wilson wrote: "...that the discontinuous long poem, the cyclical short poem and the cycle of lyrics have always been the most fruitful cluster of genres in our poetic history" (Wilson, 1971:199). Academic interest on the subject has not diminished over the last few decades ${ }^{2}$. Still, Louis Dudek's long poems have received little critical attention, despite the fact that this writer is considered by many as Canada's "most important -that is to say, consequentialmodern voice" (Blaser, 1992:19). Dudek has expressed his discontent and frustration over this oblivion on several occasions. For example, in a letter addressed to Sam Solecki, he confesses: "My writing in general seems to be very difficult for Canadians to grasp as a whole" 3 . Dudek is referring not so much to his lyric poetry as to his long meditative poems:

As a result [of the publication of these poems] I practically disappeared from the scene of Canadian poetry for two and a half decades; and it is perhaps because some other poets have begun to write this same kind of poem, out of inner necessity, that I have surfaced now a bit (Dudek, 1992:81-2) .

\footnotetext{
${ }^{1}$ I am grateful to Sam Solecki, University of Toronto, for going over this paper. I am also grateful to Catherine Hobbs and Linda Hoad, archivists at the Literary Manuscript Collection at the National Library of Canada, for their help with the Louis Dudek material. The same is true for Louis Dudek himself, whose comments provided the guidance and insight that only the author can give. In these pages I wish to pay him a modest homage in the year of his death.

${ }^{2}$ Cfr. (Davey, 1983; Jones, 1995; Kamboureli, 1991; Kroetsch, 1989; Livesay, 1971; Mazzof, 1998; West, 1971). See the articles included in "Long-liners Conference". Special issue. Open Letter 6: 2-3 (1985).

${ }^{3}$ Letter to Sam Solecki, August 15, 1979. I would like to thank Sam Solecki for allowing me to quote from this letter.

${ }^{4}$ As a foreigner, I have always been surprised at the lack of interest Canadians have shown for their Modernist poets. I am referring, obviously, to Louis Dudek, but also to Irving Layton, Al Purdy, P. K. Page and Margaret Avison, among other writers. I have several hypotheses that may account for this situation, but none of them so convicing as those provided by Sam Solecki: "Why Canonization has been coextensive with neglect is clear, in part, from the titles and concerns of many of the essays in the journals: in are contemporary literature, feminism and feminist poetry, postmodernism, language poetry, colonial
} 
Curiously enough, Dudek's long poems, as Douglas Barbour has rightly pointed out, explored new paths that were subsequently followed by other Canadian poets: "He is the only one of the three Cerberus poets even to attempt a truly long poem. He has walked the paths of his arts alone. If he has not been completely successful in his poetic quest, surely one of the reasons is that he had to do it all by himself: he had no other poets in Canada to share his particular problems and efforts" (Barbour, 1972:21).

Dudek, it seems to me, never felt at home with the strict limits that the lyric genre imposes on the writer. Thus, after the release of a series of books of lyrics (The Searching Image (1944), East of the City (1946), Cerberus (1952), Twenty Four Poems (1952)), he came to experiment with the long poem; something he did until the end of his work. In Dudek's opinion the long poem offers the modern poet a new range of possibilities: "For this is the key to the long poem (...) It is the mind that is entirely open, incapable of "closure", that generates the verbal form, equally open, fragmentary, disjunct, spasmodic. The poetic mind today is open to all possibility and speculation..." (Dudek, 1992:98). Dudek consequently regards the long poem as flexible enough, a perfect medium with which to develop the meditative poetry he is so fond of. In this sense, we should not forget that one of the writer's permanent complaints concerns the progressive withdrawal of modern poetry from deep and serious thought: "Poets are not supposed to be thinkers, is the common conclusion. Well, if they're supposed to be prophets, I will make a prophecy -that they will become thinkers, in future-- What have they to lose? Only their sense of inadequacy and their present intellectual vacuity" (Dudek, 1992:79).

One of Dudek's continuing interests, as Douglas Barbour has judiciously observed, was the process of thought: "His poems often provide paradigms of that process, or icons of the results of that process" (Barbour, 1972: 19). The modern long poem is, by its very nature, a poem in process, a genre that operates in the present tense. Robert Kroetsch mentions the deferral of orgasm in relation to the long poem, noting its rejection of any pre-formalized versions of closure: "In love-making, in writing the long poem - delay is both-delay is both technique and content" (Kroetsch, 1989:117). Frank Davey emphasizes the impulse "not to delay, but to prolong: to have the poem not to be about time but in it, not to be about the life but within it" (Davey, 1983a:188). Dudek, on his part, speaks of a search: "The real subject [of the long poem] is a search, the search for a truth of personal being and experience such as poetry has never been privileged to explore. It is a voyage in a new found land" (Dudek, 1992:85).

The travel metaphor is not accidental in Dudek's case. Atlantis is modeled after his second visit to Europe, and both En Mexico and Europe, as their titles indicate, are also structured on the basis of a particular voyage: "I hate travel -Dudek concludes- but all the poetry I've ever written seems to be about travel" (Dudek, 1967:9). These poems therefore

and postcolonial theory, and various so-called theoretical approaches; out are the poetry and fiction of the first generation of Canadian modernists, especially those whose work does not lend itself to these approaches. Put another way, the age of Layton and Purdy has given way to that of Atwood and Ondaatje; Northrop Frye and George Woodcock have been succeeded by Robert Kroetsch, Frank Davey, and Linda Hutcheon...(Solecki, 1999:xi).

${ }^{5}$ Frank Davey and bp Nichol share the same opinion: "His long poems, the first major modernist poems in Canadian literature, open up formal possibilities which are later to dominate important work by Marlatt, Bowering, Nichol, Lee and Kroetsch" (Davey, 1981:7). See also (Francis, 1964). 
account for a specific journey but, what is more important, they also stage a radical literary experience in which the poet strives to recognize and reaffirm himself in language:

The idea of a voyage exists as an image in my Europe poem, and in my Atlantis poem, profoundly so (...) It arose from the fact that I was on a trip, and I used this actual experience as imaginative material, and I structured the poem in what Frye would probably call an archetypal way around a metaphorical voyage. What happened actually to my poetry, you see, is that it took a direction evolving out of itself-not via Pound or anybody else- namely, toward a fragmentary and continuing process of meditation and creation (Nause, 1976:48).

Traveling is important to Dudek inasmuch as it involves a process, a permanent questioning of our everyday reality: "Travel, or change of scene, has the effect of making us realize the arbitrariness of all reality (...) It's a poetic disturbance in the world of appearances" (Dudek, 1983:61). Yet, we will see how Dudek abandons the travelogue design in his last long poem so as to avoid any narrative progression or symbolic structure. This determination is, to a great extent, the responsible element for one of the greatest experiments in contemporary Canadian poetry, Continuation, "the most highly fragmented and potentially incoherent of all Canadian long poems (Nichol's Martyrology not excepted)" (Trehearne, 1999:245).

Louis Dudek's trajectory in his long poems can be seen as an adventure -a voyage, if you like- towards knowledge. This intuition is based not only upon his works, but also on the poet's various theoretical manifestations which supply valuable clues in this respect. In the book Ideas for Poetry, for example, Dudek explicitly reveals the great tragedy of man in the face of life:

Each living creature is endowed with some means to know the world, so far as this bit of knowledge is necessary to its survival, but this is not knowledge of the world as it is, it is not the real order of the world but only such a form of knowledge as is useful for life. An ant knows one world and an eagle knows another; and so does man. All our thinking and science cannot get beyond this fact of tentativeness and relativity of knowledge (Dudek, 1983:44).

But this undeniable limitation of man should not lead him to be paralyzed, as it is only in his search for the unattainable knowledge that he will be able to escape the absurdity of existence and reach the highest form of dignity: "The work of creation is always before us, to be read and interpreted; and if we approach it, not as dumb beasts, but as men, with our whole minds, it will not fail us. That is the answer to nothingness and to triviality" (Dudek, 1979:50).

Like all poets, Dudek explores reality through poetic words in search of an interior, subjective, and personal form of knowledge. This is characteristic of poetry, which comes

\footnotetext{
6 "A poem, of course, is partly about experience and existence as we know it. But its greatest power, if it is a true poem, derives from the faint hint or suggestion it gives of that order, unkown world of being", Louis Dudek "The Theory of the Image in Modern Poetry" (Davey, 1981:281).
} 
about through the sensorial and emotive contact of the poet with reality and through the magical combination of words ${ }^{6}$. But Dudek has also defined the need for poetry to seek a more objective and rational form of knowledge, found characteristically in thought and reflection. In this instance, it is a knowledge of intersubjective and collective legitimacy which originates in lucid reflection on reality. This form of knowledge is generally overlooked by poetry and associated with prose and disciplines such as philosophy?

This poetry of reason requires the poet to broaden his horizons and open his mind to new approaches and themes. This explains, in part, Dudek's decision to write long poems, a form of writing that proves to be an ideal means of analyzing and reflecting upon various aspects of reality, as well as a formula that allowed him to reintroduce themes dealt with earlier. In his long poems, Dudek intends to benefit from both subjective and objective knowledge, seeking in both an opening towards a form of transcendence that, after all, seems to flee him:

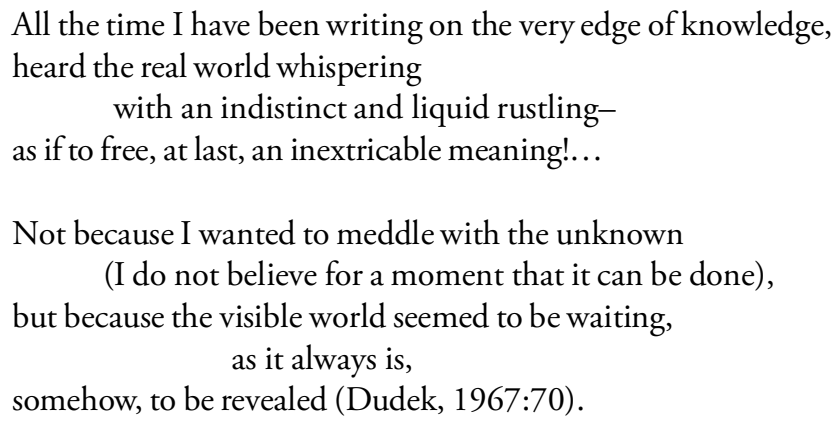

This tension between the subjective and the objective decisively conditions the style of these poems, which can go from intense lyricism to essay-like monotony and to epigrammatic abstraction.

We may consider Europe as the start of this venture towards knowledge. This sailing after knowledge is also a crucial motive in Dudek's poetic father, Ezra Pound, who begins his Cantos with these words:

And then went down to the ship,

Set keel to breakers, forth on the godly sea, and

We set up mast and sail on the swart ship (Pound, 1993:3).

Following the path marked by Pound, Dudek also begins his long poem by setting sail for the sea in a voyage that is essentially a search for our origins and the legacy of

\footnotetext{
7 There are various references from Dudek regarding the relation and differences between philosophy and poetry: "There is an ancient quarrel between the poets and the philosophers, as we know; and if it is in order for the ringmaster of all philosophers, Plato, to write a humorous [but earnest] repudiation of poetry [as a way to truth] in his Republic, Book X, why should not the poet throughout all do likewise? This only sets off for us the difference of viewpoint, the difference of approach to experience, of the disciplines. They all want the ultimate truth, "gods", the love of earth for their own", "E. E. Cummings", Louis Dudek Papers at NLC.
}

Odisea, $n^{\circ} 4,2003$ 
knowledge. Whatever the degree of Pound's influence over Dudek may be, it is true that Europe would not have existed without Dudek's reading of The Cantos. Dudek's poem, on the surface, scarcely resembles Pound's epic. We do not find in his pages the strong juxtapositions of the ideogrammatic method, nor does the author exhibit Pound's vast encyclopedic learning. Yet, as Harold Bloom reminds us, "poetic influence has almost nothing to do with the verbal resemblance between one poet and another" (Bloom, 1980:19) ${ }^{8}$. Like Pound, Dudek felt the need to make the leap towards the long poem and begin his particular voyage to knowledge. Dudek's didacticism responds also to a desire to denounce the corruption of our civilization as well as proposing a sort of cultural regeneration that would somehow act as a counterweight to the vulgarity of modern culture. Pound looks back to older traditions in order to affirm the gold thread in their culture. In Europe, Dudek attempts to do a similar thing, traveling to Europe to 'reevaluate his past and present culture to salvage what he can' (Reed, 1998:149). But Dudek does not find these answers in the Old Continent.

The feeling of deception is strong in the 'Italy' section. The thought of Rome being her own sepulchre has long been a theme in Western literature?. Francisco Quevedo's "A Roma sepultada en sus ruinas" and Du Bellay's third sonnet in Les antiquitéz de Rome, to point out two examples, are addressed to a traveler who is eager to see with his own eyes the wonders of the Eternal City. But if the medieval pilgrim was satisfied at the end of his journey and gave thanks to the Lord for having reached the holy site, the modern traveler in these two poems, in his search for the splendours of antiquity, is disappointed at the sight of the city's decay:

Buscas en Roma Roma, ¡oh peregrino!,

Y en Roma misma a Roma no la hallas:

Cadáver son las que ostentó murallas,

Y tumba de sí propio el Aventino (Quevedo, 1963:260).

Nouveau venu, qui cherches Rome en Rome

Et rien de Rome en Rome n'aperçois,

Ces vieux palais, ces vieux arcs que tu vois,

Et ces vieux murs, c'est ce que Rome on nomme (Du Bellay, 1945:4).

Dudek, like Quevedo and Du Bellay, was unable to find the splendors of the past: "The present is all too present/and the past all too past". Rome has become a corpse, a mere cluster of ruins. Here Dudek begins to point out the inexorable passing of time, "qui tout consomme"; a notion that he will clearly express in Atlantis:

In Rome, where the cities are heaped on one another, the new most powerful,

\footnotetext{
${ }^{8}$ Dudek himself has admitted this deeper influence or anxiety: "In my own poetry Pound is present mainly in the theoretical presuppositions which I derived from his poetry, not in the actual imagery, or language, or rhythm of the poetry" (Dudek, 1978:214).

${ }^{9}$ For further information on this topos see (Ortiz, 1927).
} 
shouldering away the past, yet unwilling, or unable, to erase those monuments, Time makes it an accumulation of glorious rubbish that once was real (Dudek, 1967:44)

Curiously enough, Pound has a poem dedicated to Rome, which is a close translation of Du Bellay's sonnet:

O thou new commer who seek'st Rome in Rome

And find'st in Rome no thing you can call Roman;

Arches worn old and palaces made common,

Rome's name alone within these walls keep home (Pound, 1928:63).

Unlike Du Bellay or Quevedo, Pound's poem is preceded by some words from Propertius' fourth Book of Elegies: "Troica Roma resurges". Propertius is prophesizing the rise of Troy as a new Rome. Pound, on his part, suggests the idea of Rome rising again as well: "Thou, Troian Rome, shall rise again". The quotation shows Pound's desire to go beyond the mere lament of the faded glory of the past and profit as much as possible from the formative element of Europe, which he refers to as a "return to origins" that "invigorates because it is a return to nature and reason" (Pound, 1968:92) ${ }^{10}$. Contrary to Pound, Dudek does not, in the end, marvel at the cultural richness of Europe, but, rather, is disappointed by its decadence and submissiveness to American tourism and capitalist standards. In his "Epilogue" of 1912, Pound brought back from Europe his gifts to America to achieve an "American Risorgimento":

I bring you the spoils, my nation,

I, who went out in exile, Am returned to thee with gifts.

I, who have labored long in the tombs, Am come back therefrom with riches. Behold my spices and robes, my nation, My gifts of Tyre (Pound, 1976:209).

Dudek, on the contrary, does not seem to find the riches described by Pound. What he finds are ruins and poverty. It is understandable, therefore, that Dudek should finish this section with a chant of North-American self-assertion:

But I would rather have my friend's new poem than all the Coliseum, which is a blood-stained stable, fallen in ruin, and your kind letters, than all the sculptured words in all the crumbling friezes (Dudek, 1991:106).

\footnotetext{
${ }^{10}$ A study of the variations of Pound in the translation of Du Bellay's sonnet can be found in Smidt, 1993:61-7.
} 
In poetic terms, Dudek therefore swerves from Pound so as to intone a Whitmanian chant about the potential of America and the decadence of Europe. If Europeans can no longer proceed with this journey, then it is time for North Americans to carry on: "we have lots to do, we in America,/who know that there is no end to the journey" (Dudek, 1991:138). Dudek ends Europe just as he began it, navigating down the St. Lawrence river, now a gateway to a land promising the future. In the end his voyage did accomplish its initial mission of finding the answers sought by the poet in the Old Continent. On the other hand, what the voyage did succeed in is making him acknowledge the potential of his homeland: "We have our physical heroes,/and are also a nation/built in the middle of the water... a country with certain resources" (34). Dudek, therefore, rejects both the idea that Canada is a colonial country and its inferiority complex with respect to Europe. In an interview with Dorothy Tooker, William Carlos Williams responded to a question on whether American writers lacked the refinement of Europe by saying: "Go to Europe by all means. Go to see and learn. But not to imitate. I don't want to sound overly jingoistic, but the fact is that the world force is today here. Here in our own country. We must take advantage of it, work with it, use it" (Wagner, 1961:34). It was also the advice of Pound that Dudek followed in traveling to Europe, but like Williams, he only ended by exalting the potential in America:

$$
\begin{aligned}
& \text {...the New World is every bit as good } \\
& \text { as the immigrants imagine } \\
& \text { (40,000 applicants, } \\
& \text { of whom ten per cent will be lucky), } \\
& \text { where wages are high and the standard of living } \\
& \text { goes up with the increasing manufacture } \\
& \text { where the installment plan makes sure } \\
& \text { you can buy some of the overproduction...(Dudek, 1991:128). }
\end{aligned}
$$

Dudek therefore rejects the notion that an American culture could not exist without a close connection to the cultural developments and heritage of Europe. The American culture that attracted Pound was the 'Franco-English' America of Adam and Jefferson. Dudek, on the contrary, sets his sights on the future of the New Continent, on the culture to be forged by the immigrants, the workers and the factories. This was a new culture that was no longer to be shadowed or 'tutored' by Europe, "though it will take time/before a material civilization/discovers the language of its self-applause" (144). Pound -writes Christopher Beach- could not agree with Whitman that "to have great poets, there must be great audiences too" (Beach, 1992:70). As did Williams, Dudek had aspirations of reaching a vast audience with this long poem. After the publication of Europe and the cold reception of this work by the critics and public alike, he suffered 'a sort of defeat'. As a consequence, Dudek's subsequent long poems would abandon the public voice and rhetorical language of Europe, turning to increasing fragmentation and more intense subjectivity.

It is not surprising that Dudek should choose Mexico for his next voyage and adventure. As opposed to the stale knowledge he found in Europe, Dudek searches Mexico and the fertility of its jungle for a new form of wisdom: 
To discover the elements, to define the natural

and then the skill-won form;

to reconcile these

with the real conditions

of living, which are universal carnage

in a jungle of fertility,

under the aspect of new knowledge

not of old mythology (Dudek, 1958:17).

Perhaps as a response to the many museums and ruins seen in Europe, we find that $E n$ México diverts its focus to a type of knowledge that is more essential and derives from the communion between the natural world and a more primitive country: "And I do not know why a leaf should be less worth/than a Vatican" (21). It is therefore no wonder that En Mexico is Dudek's most lyrical long poem. Moreover, the poem no longer hosts the almost essay-like diatribes and reflections detected so amply in Europe and Atlantis, and which, on occasion, and in spite of the intense fragmentation, also appear in Continuations.

The poet aspires to complete knowledge in the cosmic communion with nature. However, as he progresses in his journey, the environment is an aid in humbling him with regard to man's limitations in the face of creation: "We can define the elements, their order,/and what they do in their eye, or mind-/but the shaping hands are undivined" (30). This attitude substantially decreases the poet's inclination to explore and explain, so evident in the previous long poem: "I would not pretend/to explain,/but learn a stoic silence,/a little joy" (57). Another difference between En Mexico and Europe is the attitude of the poet towards nature. If in the past the poet was incapable of assimilating the totality and chaos of the unbounded sea, he now seems much more in harmony with the jungle:

$$
\begin{aligned}
& \text { You may hate the jungle, } \\
& \text { its inimical insects, flies, } \\
& \text { and the chaos of growing } \\
& \text { everything at once; } \\
& \text { but we return for fertility } \\
& \text { to its moist limbs } \\
& \text { and the vaginal leaves (34). }
\end{aligned}
$$

En Mexico and Europe are also substantially dissimilar in terms of their formal qualities. As a matter of fact, En Mexico is a pioneer poem in its time that has been unjustly disregarded by the critics. In it we find references to ideas that are widely used today, such as the conception of the poem as a continuous process, rather than a textualization of reality. One of the main differences between En Mexico and Europe is that the first requires much more active collaboration from the reader. Although still only discreetly, the text bids us to 
continue its process, rather than simply contemplating its form or receiving its message. Europe exhibits a clear organic form. The travel route, designed with great care, endows the poem with a lineal progression, which the author himself outlines in the 'Prologue': "I. Sea and Land', 'II. England', 'III. France', 'IV. The Warm South', 'V. What Greece Has Given', and 'Finis'); (Dudek, 1991:15). En Mexico is not organized as neatly as Europe. The first edition displays a fragmented poem that rejects an arrangement into formal sections. The second edition presents a poem divided into six parts, with no epigraph, and the poems of each section printed as if evolving an ongoing process. En Mexico seems to have been written without a previous plan, as the author himself confesses: "Now the poem is fascinating in the way it got the form it has because at the time of writing I had no intention; I had no purpose in mind and there was nothing that I even vaguely proposed to myself as a subject" (Schrier, 1990:47). Dudek discovered when writing this poem a more spontaneous method of composition, which he has described as follows:

Now, in En Mexico I just collected lines, sometimes two or three lines, sometimes more, and wrote them on scraps of paper. And then I brought all this home, and right on this table I laid it out piece by piece. They were lines and passages in no particular order. I said, "Jesus! What am I going to do with all this?" There were no sequence, no form. Of course I could remember that some of the lines were from the earlier part of the trip, some from the later, there was a kind of possible order. So you could look at the poem to see if there was a progression in my thought-process through Mexico -but maybe there was not (Schrier, 1990:48).

The process of editing turns, then, into a personal adventure, and the poem emerges as an improvised framework that puzzles the writer: "I arranged the poem right here on the table, in what looked like an emerging form. And then I typed it, and I moved things when I needed to, until I got a damn good poem out of it" (Schrier, 1990:47). En Mexico, therefore, reveals a drive towards fragmentation.

It must be said, however, that a lineal progression can be discerned as we study the poem in greater depth. As a matter of fact, En Mexico is a crisis poem. In an interview held in June, 1982, Roy Everson argued that "Louis' poetry in En Mexico is very vivid and intense, similar to D. H. Lawrence's Morning in Mexico" (Stromberg, 1983:98). I would rather read Dudek's poem against William Carlos Williams' "The Desert Music"11. Based on a brief trip across the Mexican border in 1950, "The Desert Music" can be regarded as a poem of crisis written by Williams "quite simply to prove to himself that -in spite of very strong intimations of his own mortality- he was still a poet" (Gould, 1995:125). As typical poems of crisis, both En Mexico and "The Desert Music" follow the symbolic design of falling and rising. Williams' instinctive response after his encounter with the aboriginal American culture "is not wholly one of revulsion, though that seems dominant" (Sherman, 1968:85). Dudek's arrival in Mexico, on its part, reveals the poet's confusion and his

\footnotetext{
${ }^{11}$ There is a reference to William Carlos Williams in the original first draft of En Mexico: "Met a teacher from Paterson New Jersey/ who had never heard of / William Carlos Williams". Worksheets. Louis Dudek Papers. NLC. 83.
} 
uneasy confrontation with the misery and squalor of the country: "Besides the ditch the boy was defecating... They live in hovels, on the harsh crude maguey" (Dudek, 1958:197). After these initial and striking images, the poem reflects on the cruelty of the past and the alienating effect of religion, "always used to put a safe stamp on terror. First the enemy one hates is "sacrificed" then one's own kind-to contain fear out of ignorance" (202). In the case of Williams' poem, the symbolic turning point towards ascend comes with the dance of a stripper which catches the poet's imagination:

\author{
Look at those breasts \\ There is a fascination \\ seeing her shake \\ the beaded sequins from \\ a string about her hips \\ She gyrates but it's \\ not what you think, \\ one does not laugh \\ to watch her belly (Williams, 1988:279).
}

The physical dance, according to Paul Sherman, involves several kinds of dancing or action: "that of coming into contact with the world, that of discovering the particular motions of particular things, and that of creating (inventing, composing) the poem, which is itself the result of the previous actions in the world and objective representation of them on the plane of the imagination" (Sherman, 1968:85). En Mexico's symbolic ascent is, however, more gradual and subtle, though it reaches a climax in the passage of the beach in which the dance also plays an essential role:

Beautiful people,

Creole, Mexican, Spanish

in their variety.

To native music, as we heard it at night by the water,

a trio against the tireless surf

singing (forgetting lines)

with plangent voices,

the guitar thwacking and thrumming into the surf beat"

And beautiful servant girls

out of Gaugin, holding their breast as if for an offering,

bending quiet religious eyes (Dudek, 1958:206).

"The stripper in "The Desert Music" -Paul Sherman defends- is another embodiment of the Beautiful Thing [Williams] has pursued. She is America" (Sherman, 1968:87). The big mother, with her dancing children, in Dudek's poem stand also as the representation of the vitality and artistic potentialities of the New Continent: 
And of larger proportions, grander, a magnanimous mother with children

dancing toward the shore, in a night-dress, her opulent ankles tapering down to her toes (behind her children shrieking), stood poised, supremely graceful, giganticAmerica, the Continent dancing (Dudek, 1958:207)

Williams' renewed contact with the environment led him to reaffirm his vocation as poet: "I am a poet! I/am. I am. I am a poet, I reaffirmed" (Williams, 1988:284). Dudek also claims in his poem that "Poetry is my language". The final line of section 4 even seems to point at Williams' famous lines: "Where all roads come together/to a place of storm, or sun,/the poem begins proclaim-"I-am-that-I-am" (Dudek, 1958:208). Both "The Desert Music" and En Mexico end with the poets' serene thoughts. Williams faces death in this poem and concludes that it begets life and renewal. Similarly, Dudek has 'looked death in the face' to discover that "also death is in the process"; that "perhaps we die to make room for others". Now he feels that the harmony of his self, as a poet, and his relation to the environment has been restored:

Therefore art is everything;

but not as we imagined.

Art is the way of life (Dudek, 1958:213)

This personal evolution actually slows the characteristic curving and disjunctive motion of what seems at first a serial form poem. Therefrore, if faced with the choice between the two denominations, serial and sequence, we would have to conclude that $E n$ Mexico is a meditative poem in sequence form. In any case, we must admit that En Mexico represents a significant evolution with respect to Europe, a change which specifically stands out in the style. En Mexico is therefore a poem of transition, hinting at some of the characteristics of the contemporary Canadian long poem: namely the conception that what is read and what is written are part of a continuous process of creation and recreation, but also that the poem is a motive for new experiences, rather than simply a product. This idea will obsess Dudek throughout his literary career.

Reading En Mexico, we are left with the impression of a poet satisfied after his encounter with the new surroundings. Dudek's intellectual curiosity, however, does not end with the Mexican experience: "There is more than one road", he writes at the beginning of Atlantis, and this makes it necessary to begin his travels once more, on a new journey. With Atlantis we can clearly note how a basic idea stands out, an idea that permeates Dudek's philosophy: the conviction that knowledge is not so much an achieved state, as a form of continuous search. This idea runs parallel to the conception of the poem as a continuum, a constant stream, like a universe of its own in which the poet can unfold his craving for knowledge 
with no limitations of space. This explains why Dudek would refer to Atlantis as an 'infinite poem' and why he would begin his next long poem with the invitation "Let's continue".

The fragmentation and inward turn of En Mexico is certainly a passage towards the style of Atlantis. But Atlantis is essentially a breach, a reaction to the fulfilled state achieved in En Mexico. Intellectualism replaces primitivism now and this explains, not only Dudek's return to Europe, but also the wider thematic range of the poem and its consequent 'greater density of reference and discourse' ${ }^{12}$. If the reading of En Mexico leaves us the impression of a poet who has found the answers he was searching for, we need only make a small list of the poet's interrogations in Atlantis to verify that he has not resigned himself to the humble and passive attitude of those who do not 'pretend to explain'.

Time and again the poet asks himself and meditates about the nature of reality. The diversity of themes in the poem can be explained by Dudek's complex conception of the reality that surrounds him and by the magic that it hides. The poet acts as if he wanted "to make a master diagram/of all that is or even was,/all the processes, manufacturers, all knowledge-/to know them, to fill in the gaps" (Dudek, 1967:89). In this way, the poet embraces and abandons various questions and themes in a never-ending search. There is a clear desire to organize, to shed light on the chaotic flow of existence and the immensity of information and details that it comprises: "order, kosmos, the unknown process./Without it there is only the flux" (117). Ironically, Atlantis and Continuations are the Dudek poems in which the flux is more intense. The chaotic arrangement of fragments in the poems stands out as an emblem of the incapacity to establish this order: "Who am I, wandering about the world?/The failed traducer-/vain idealizing peacock-/who crystallize all things spontaneously" (83). At times the poet seems to lose his strength and to feel a need to let himself be carried away by the flow of existence.

Atlantis can be viewed as a spiritual journey in which the Dudek embarks on a search for, what he calls, 'the other half of existence'. Dudek has explained that after the Enlightment and the French Revolution -i.e. after the 'rationalist harrowing' of religion- there was a sort of reconstruction carried out by Romanticism. Yet after the decline of Romanticism, which degenerated into sentimentalism, and with the advance of science and realism, it came a 'great vacuum of negation' that permeated the thought and art of the $20^{\text {th }}$ century:

T. S. Eliot's solution was an arbitrary return to Anglican Christianity. (Note that his longish poem The Waste Land (1922) was often taken to represent the meaningless modern world without religion, which in fact points in the opposite direction. It expresses a thirst for religious meaning). My poem Atlantis has a similar predicament to that of Eliot. As I have explained earlier I had been teaching literature from the $18^{\text {th }}$ century to the present for years, and this had inevitably been an account of Romanticism and its negation. But just before writing Atlantis I came to realize that this universal skepticism and demolition of past beliefs - this nihilism of Bazarov- must be only half of the truth, that the other half is the idea just the idea- of a great good, of perfection, and that reality only occasionally and in some part attains it (...) So that when in a moment I gave it the name of "Atlantis" the whole thing crystallized and the poem began to write itself ${ }^{13}$.

\footnotetext{
12 I borrow the expression from Trehearne, 1999:280.

${ }^{13}$ Letter to Antonio Ruiz. November 7, 2000.
} 
Brian Trehearne considers Atlantis as a step forward towards the limits of poetic coherence we find in Dudek's final poem Continuation. Trehearne is right when he emphasizes the fragmentation of the poem. Still, he fails to notice that behind the apparent flux and meaningless combination of particulars a vision is implicit.

Gradually, we realize that Atlantis is essentially the representation of a mind searching for definite answers, for a definite state in which opposites are reconciled and the sublime is found in the flux of our daily experience: "Someday, in the great future, perhaps/there will be men/no longer torn,/for whom time is one eternal now/and change and everunchanging change,/who see the permanent in the impermanent" (Dudek, 1967:127). The desire for order and knowledge is too strong in Dudek, who warns us of our responsibility towards those who will come after us: "Whatever it is, since there will be others after us/(by some necessity),/it is important that they should not be lost;/that we discover, add to, do whatever helps/to enlighten them" (90). This desire for order brings the poet to a moment where he embraces an ideal, Atlantis, that may give him the desired final coherence and spiritual integration: "An architecture of contradictions and inexorable chances/reconciled at last,/in a single body" (148). For generations the Atlanteans lived a simple, virtuous life $^{14}$. Similarly, we find in these pages, as in the closing lines of En Mexico, an explicit desire to live a more simple life: "Learn to be practical, simple and kind". Atlantis, however -we learn right afterwards- is a North Atlantic iceberg the poet spots from the cruiser: "The iceberg came toward us, /like a piece of eternity,/like a carved silent coffin, out of the night,/and stood in the shattering sea, serenely still'. Dudek's need to control his moments of illumination so to avoid any visionary flight is evident once again. In this sense, the final lines that follow the litany can be considered, if not an anticlimax, at least a recognition of the impossibility of achieving a final, supernatural truth that may give us rest:

We come to land by a pleasant shore:

to roads, houses, people

we have not seen a long time,

so that our dreams must be corrected by the familiar still (Dudek, 1967:150).

Dudek's adventure, therefore, does not end in this climax. And so, years later he would write in Continuation: "Still trying to find that meaning which eludes us/to say why the molecule prances" (Dudek, 1981:15).

Continuation $I$ is a new attempt to go beyond appearances and search for truth. But the verses of this poem, lost in the maze of the mind, do not seem to bring us anywhere in particular. I would therefore agree with Brian Trehearne who, in reference to this poem, speaks of 'accumulation' instead of 'continuation': the latter "implies a greater degree of linearity"; in accumulation, on the contrary, "adding to is the point, not necessarily expanding or persisting with " (Trehearne, 1999:245). Continuation, like William Carlos Williams' Kora in Hell, is a tour de force that requires an aggressive reading. The

\footnotetext{
${ }^{14}$ On the myth of Atlantis, vid. Plato's Timaeus and Critias. "Atlantis here is suddenly a kind of paradise on earth: but it is potential, not yet realized. In fact it is a vehicle for all the ideals, for the good". Louis Dudek "In a Nutshell" (Hildebrand, 2001:116).
} 
fragmentation and incoherence of both books, however, serve different ends. As a radical gesture, Williams launches an attack on reason to dislodge the mind from its fixities and destroy obsolete forms of thought so that we can see "everything afresh"15. Dudek's intention is far less radical, and the random flux of language in Continuation attempts to achieve an imitation of the mind at work:

Continuation $I$ and $I I$ are simulations of the mind thinking. Of course it is not the actual content of any 'stream of consciousness', for that would be chaotic, messy, absurd no work of art. I accumulate in my notebooks only those lines and passages that come to me unbidden, that drop down form the blue, so to speak (...) I find that the lines accumulated in this way have a peculiar connectedness in their progression, and I shape the whole sequence into a flowing, uninterrupted poem. It corresponds, as I see it, to something that is going on in the most erratic and vivacious area of my mind...(Treherane, 1999:253).

Brian Trehearne argues that the Continuations project "is itself coherent -and only soas a representation of the motion of content and phenomena in the poet's mind; specifically in Louis Dudek's mind, for the particularity of its references allows no other personality to materialize" (Trehearne, 1999:250). Adopting the mind as a principle of structural order has the advantage that the "energy of fragmentation, the ambiguity of reference, the subtlety of connotation, are now predicated as forms of mental energy, as motions of consciousness, and whereas our conscious desire for clarity remains frustrated, a new pleasure emerges in that we are sharing the ambiguities and liberties of consciousness with another" (257).

Despite Trehearne's advice on how to approach Continuation I, it is difficult to enjoy the reading of the text. Our frustration, in my opinion, does not arise only from its obvious fragmentation, but also from the very general abstract dimension in which the poem places us. In his desire to recreate the motion of the mind, Dudek almost dispenses with specific dramatic contexts or imaginary situations in Continuation I. The meaning of the poem seems to reside almost entirely in the motion of the mind, thus recalling Mallarme's claim that the mind's action at once makes and becomes a place sufficient unto itself. The fragments hardly offer any sensuous appeal or personal drama, and are settled in an abstract and self-sufficient dimension in which everyday reality seems to have been superseded: "I am the imagination/that creates itself" (Dudek, 1981:20). As in Action painting, in which the act of painting itself is emphasized, the poem calls our attention to the process of writing: "Putting together lyrics" (11); ..."Accumulate, accumulate" (14). The poem not only lacks personal drama, but extreme fragmentation prevents the consolidation of philosophical or meditative discourse. As a result, generalizations and epigrams seem to float freely in the text, liberated from any interpretative function. Devoid of any illusionistic drama, narrative or symbolic construction, the poem seems to rest solely in its own rhythm, in the movement of the mind in action. One fragment follows another, creating odd and sharp juxtapositions in a seemingly never-ending process.

\footnotetext{
${ }^{15}$ Kora in Hell is one of the most obscure and challenging books of American literature, a work Williams was proud of: "... a unique book, not like any other I have written (...) It reveals itself to me and perhaps that is why I have kept it to myself" (Williams, 1958:23). The book is structured in twenty-seven sections, each divided into three parts. The different sections do not follow any lineal order and they lack a stable thematic development. Kora in Hell is, to a great extent, the result of dadaist improvisation techniques adopted and adapted by Williams in which hazard and chance are true motors of the creative process.
} 
Continuation I shares the desire of the postmodern Canadian long poem to emphasize the materiality of language and question the Cartesian ego. Intense fragmentation, unmediated presentation and its abstract quality, assembled on the basis of the epigram, make it difficult for the poem to evoke metaphysical presence. The integritas of the poem is thus imposed by the reader rather than discovered in the text. Certainly, anyone familiar with Dudek's poetry will recognize some of the ideas and thoughts in the poem as typical of the author. Yet it is necessary for the reader to have this background to provide this desired contextualization. The abstraction here becomes the site of poetic activity in which the different fragments interact in the constant movement of the poem. Continuation $I$, therefore, pushes the reader to face selfhood as a construction to be gained during interpretative process of the reading act. In order to fight traditional modes of lyricism, Dudek has adopted a different strategy from other poets of the second half of the $20^{\text {th }}$ century. I cannot see in Continuation I the well-known 'novelization' of the Canadian documentary long poem. Neither can I perceive a desire to excavate in the ground of the unconscious, something which may account for the lack of any surrealistic quality in the poem. Nor is there an intention to remain in the dramatic domains of confessional poetry. Rather Continuation I remains in the abstract levels of the intellect on which the poet relies in his quest for insight into himself, life and his writing.

In Continuation I there is no teleological progress toward final climax, and no one fragment in the poem explains or proves climactic for the others. In this sense, and with the exception of Section IV, Continuation I is a long poem in serial form which, according to Joseph Conte, is radically incomplete, random and accumulative (1991:21): "But to accumulate lines, is not a pleasure?/To weave them into patterns/is not that happiness?" (Dudek, 1981:13). Things however are not so simple. Dudek has oftentimes manifested his enthusiasm for 'multiplicity, and actuality, and a forever expanding field of unpredictable useful meanings' (Dudek, 1978:370). The contemporary long poem is, according to Dudek, inevitably fragmentary, "for this is the key to the long poem, and also to what we call 'open form'. It is the mind that is entirely open, incapable of "closure", that generates the verbal form, equally open, fragmentary, disjunct, spasmodic. The poetic mind today is open to all possibility and speculation..." (Dudek, 1992:98). Robin Blaser has written that the "openminded problem, which [Dudek] shares with his great contemporaries and which is characteristic of what is now called post-modernism, is, in the very practice of openness, a correction of those aspects of modernism that thought to solve the order of things by authoritarian structures" (Blaser, 1992:19). Still, Dudek's desire for openness does not weaken his modernist tendency towards integration, synthesis and order: "We are struggling toward an integration that will again provide order and value to the individual, and that again may provide our society with some bearings" (Dudek, 1992:86) ${ }^{16}$. This desire for insight, synthesis and order explains the general feeling of anguish that springs from the

\footnotetext{
${ }_{16}$ Eli Mandel has emphasized Dudek's desire for coherence: "In the classical vigour of Dudek's position, incoherence (prized by younger poets) is a serious fault. His own continuing poem seeks to reclaim for poetry the territory once staked out by prose, the virtues of intelligent speech, of language that will have 'some fruitful and valid relation to that greater total existence of which we know only a small part'. He will write, continuing, discursive poetry, in touch with reality which, whatever it is, is more than told by our senses. His motto, "more ideas than in things"”, "The Death of the Long Poem" (Mandel, 1985:18).
} 
going around in circles that the poet is suffering. He himself explains this feeling in his poem "In the cage":

Day by day, in my cage of private dreams, ideas, passions,

I pace like a captive tiger, day by day.

What I once thought so free is now a prison. my mind

It holds me captive to these thoughts that used to wander through eternity, but now repeat the daily round.

I am no longer free.

What can I send you through the ribs of my cage but a gleaming tooth? (Dudek, 1997:39).

The sarcasm and irony are a logical response to this unrest: "What's going on in that stupid head of yours... does anybody care/about your precious mind?", writes the poet (Dudek, 1981:13). The references to God and old age in Continuation II y III are no more hopeful: "This world could be God's autobiography,/ a vast Bildungsroman/with billions of characters" ..."(Retirement's not so bad/except that one feels one is dying)" (Dudek, 1990:112-3). Yet the predominating feeling, both in Continuation II and Continuation III is not anguish, but melancholy. The poet in Continuation I is still a poet-philosopher, trying to go forward in his search for wisdom and the ultimate truths. The poet in Continuation II and III, on the contrary, has lost all hope that reason or objective knowledge will be able to save him. The deciphering of the problematic involving existence is now followed by the acknowledgment of the mystery of life. The poet clings to life, inebriated by its beauty and the beauty of everything that surrounds him: "the empty air and the infinite sky/beckon and welcome "all who enter here"/I walk as gay as Christmas into the morning sun,/tremendous delirium in my bones" (Dudek, 1990:83). The poet is now only clinging to the moment, and no longer accepts the consolation of reason. Life cannot be saved, and the moments that have been lived will be lost without repair. The poet regrets: "Those mortal moments!/How to resurrect them for an eternity..." (Dudek, 1997:71). Dudek's poetry, among so many fragments, now opens up to people and things.

Continuation II and III can be regarded as an experimental physiological record of the poet in his last years. A record of his poor health, of the aches and pains of old age, as well as his moments of joy. This is precisely the most important difference of these books in relation to Continuation I: we are able now to perceive a better dramatization of the self, for example, in the shifts of emotional levels and in the contextualization of psychic impulses. Abstraction is also tamed with many references to everyday life and routine. 
Dudek, for example, records ordinary conversation: "I asked the driver, 'Why do you keep it going?'/He said, 'That's for the A.C.'/(the air-conditioning)/ 'It works only when the motor's on, that's why/we keep it on"' (Dudek, 1997:71). Occasionally, he even rejoices in trivial incidents:

\author{
At last, the shower \\ one of those nifty modern gadgets \\ like an ocean-liner's master controls \\ Happy to be "with it" for once, I turned the dial on "Hot" \\ but it came cold \\ I tried "Warmer"- \\ it still came cold \\ I stood there in the drizzle cursing, \\ until it struck me, the old traveler's adage- \\ that "Hot" means Cold, and "Cold" means Hot. \\ I turned the lever for "Cold" and hot it came (Dudek, 1997:19)
}

From this poet's view, however, no incident or action seems to be too mundane. A strong attachment to life is evident in this work, in which every single moment, being exceptional and irreplaceable, is celebrated: "Thinking today/how the best performance or entertainment,/for all its art,/become tiresome after an hour or two/while ordinary life, without skill or effort, goes on and on, for days, months and years/yet never bores a normal man/(unless you have a French ennui) What is it/makes life so interesting?" (16). It is curious how Dudek's long poem, always caught up in the whirlwind of novelty and permanent change of context during the voyage, now discovers the charm of everyday life and a more sedentary reality. The sarcastic comments and the aches and pains of old age do not lessen the poet's delight at a world that still surprises him. The recovered lyricism of some passages is thus explained:

This morning, at dawn,

I walked out and saw the quarter moon

in a pale-lit sky and the looming trees

over the quiet street, where a single bird fluted

his morning song. I stood among the flowers

listening on my backyard lawn.

All day I carry within me

the silence of the dawn...(Dudek, 1997:20)

Still, these moments of beauty do not stop the poet from thinking, once and again, about death and the tragical nature of life. Cheerfulness then turns into melancholy and 
sadness: "Optimism is for the young" (90). Dudek's feeling of the proximity of death leads him to reflect on the idea of God: "God, precisely, plays dice with the universe" (35). God, however, being only a "possibility", is not a final consolation for Dudek, whose anxiety is perceived in the final section of Continuation II: "Live for the moment, like the swallow/ who rose, paused/and fell to a smooth glide/one mid-summer/like a leaf in the tall grass" (Dudek, 1990:112).

Dudek's constant effort to attain knowledge, to find the answers, now transforms into an elegy of tears for what has been given to him: "Enjoy what is given". We no longer perceive a strong will to search deep into reality, so much as a desire to stay and delight in what he already possesses:

Sunt lumina

PHAINOMENA
that shine
All things that shine
that are glad
"for this we are made"
The glory simply in being
Bright
An Appearance Erscheinung
not "mere appearance"
but a shining
EPIPHANEIA (Dudek, 1997:64-5)

Dudek relates the word 'phainomena' (from phaino, to appear, to show) to phaos (light), and both to epihaneia (appearance, manifestation). If Plato saw this phenomenon as opposed to what is truthful, to Dudek the world of appearances or representations, "the only true world", far from being a world of shadows, is an illuminated reality that now, at the end of the poet's life, seems to shine with more intensity than ever.

Brian Trehearne considers the coherence and directness of speech of Section IV in Continuation I an aesthetic fault that reduces the poem's 'diaphaneity and Heracliteanism' (Trehearne, 1999:259). The coherent passages of Continuations however, are not confined to a single, specific section and, as a result, they do not give the impression that they are something extraneous to the global design of the poem. Rather, extreme fragmentation and coherent passages alternate providing a rich and vivid picture of consciousness which does not reject emotional drama, but similarly avoids resting on traditional modes of lyric celebration. The Continuations project shares with many contemporary Canadian long poems the fascination for the flow and movement of the poem and their desire to foreground the fictions of representation of the speaking subject. The Continuations do not achieve resolved coherence, but they do not remain comfortably, or permanently, in the chaos of fragmentation. Continuation $I I$ and $I I I$ even reveal the poet's desire for synthesis and integration. Dudek sees knowledge not as a state, but as a continuous work carried out with the resignation about the limits of what can be known. At the end of his poetic career, T. S. Eliot wrote: 
We shall not cease from exploration

And the end of all our exploring

Will be to arrive where we started

And know the place for the first time (Eliot, 1974:222).

In his quest for knowledge, Dudek began his first long poem writing about the sea: "This water contains its living animals/and all the living animals the world contains/come from this water.../All that is good in us is still whatever of the sea/we contain" )(Dudek, 1991:39). Years later, Dudek ends Continuation II in a similar fashion, amazed by an ocean which still maintains all of its magic.

Frank Davey refers to Europe, En Mexico and Atlantis, as adventurous, rite poems "in which the poet commits himself to the poem without knowing the outcome" (Davey, 1980:79). Still, not all of Dudek's long poems are ritual to the same extent. The degree of experimentation, for example, varies in each poem. Moreover, not all of them exemplify in a clear way the conception of writing as a labyrinthine and uncontrolled process. In relation to the Modernist long poem, Margaret Dickie has written that 'the long composition of the long poem reveals an inside narrative of each work which reveals the poet's uncertainty of purpose, his doubts, difficulties, ambition and despair while working towards the finished or at least published version of the poem' (Dickie, 1989:4-5). In Dudek's case, the different narratives of his long poems constitute, in turn, a further account of the poet's life-long struggle with this poetic genre. Dudek, no doubt, walked a long way from the modernism of Europe to the open-serial form of Continuation, a way that stands as an emblem of the frenetic evolution of the Canadian long poem in the second half of the twentieth century.

\section{WORKS CITED}

Barbour, D. 1972. "Poet as Philosopher", Canadian Literature 53: 18-29.

Blaser, R. 1992. "Infinite Worlds: The Poetry of Louis Dudek”. Sagetrieb 11, 1: 1738.

BEACH, C. 1992. ABC of Influence. Ezra Pound and the Remaking of American Poetic Tradition. Berkeley: University of California Press.

BLoom, H. 1980. A Map of Misreading. Oxford: OUP.

Conte, J. 1991. Unending Design. The Forms of Postmodern Poetry. Ithaca and London: Cornell University Press.

DAvey, F. 1983a. "The Language of the Contemporary Canadian Long Poem". Surviving the Paraphrase. Winnipeg: Turnstone. 183-93.

1983b. The Contemporary Canadian Long Poem. Lantzville: Island Writing Series.

DAVEY, F. and bp Nichol, eds. 1981. Louis Dudek: Texts and Essays, eds. Frank DAVEY and bp NichOL. Open Letter 4, 8/9.

Dickie, M. 1986. On the Modernist Long Poem. Iowa City: University of Iowa Press. 
Du Bellay, J. 1945. Les Antiquitez de Rome et Les regrets. Paris: Librairie Droz.

Dudek, L. et. al. 1944. Unit of Five: Louis Dudek. Edited by Ronald Hambleton. Toronto: Ryerson Press.

Dudek, L.1946. East of the City. Toronto: Ryreson Press.

— 1952a. The Searching Image. Toronto: Ryerson Press.

— 1952b. Cerberus. Toronto: Contact Press.

— 1952c. Twenty-Four Poems. Toronto: Contact Press.

— 1958. En Mexico. Toronto: Contact Press.

— 1967. Atlantis. Montreal: Delta Canada.

— 1978. Selected Essays and Criticism. Ottawa: The Tecumseh Press.

— 1979. Technology and Culture: Six Lectures. Ottawa: Golden Dog Press.

— 1979b. Letter to Sam Solecki, August 15.

— 1981. Continuation I. Montreal: Véhicule Press.

— 1983. Ideas for Poetry. Montreal: Véhicule Press.

— 1990. Continuation II. Montreal: Véhicle Press.

— 1991. Small Perfect Things. Montreal: DC Books.

— 1992. Paradise. Essays on Myth, Art, \& Reality. Montreal: Véhicule Press.

— 1997. The Caged Tiger. Montreal: Empyreal Press.

Eliot, T. S. 1974. Collected Poems 1909-1962. London: Faber and Faber.

Francis, W. 1964. "A Critic of Life. Louis Dudek as Man of Letters." Canadian Literature 22: 5-23.

Frye, N. 1971. The Bush Garden: Essays on the Canadian Imagination. Toronto: Anansi.

Gould, S. and H. DeEse, eds. 1995. Critical Essays on William Carlos Williams. New York: G. K. Hall \& Co.

Hildebrand, G., ed. 2001. Louis Dudek. Essays on His Works. Toronto: Guernica.

Jones, M. 1995. The Art of Difference: 'Documentary-collage' and English-Canadian Writing. Toronto: UTP.

Kamboureli, S. 1991. On the Edge of Genre. The Contemporary Canadian Long Poem. Toronto: Toronto UP.

KROETSCH, R. 1989. The Lovely Treachery of Words. Toronto: OUP.

Livesay, D. 1971. "The Documentary Poem: A Canadian Genre". Contexts of Canadian Criticism. Ed. E. Mandel. Chicago: University of Chicago Press. 267-81.

Mandel, E. 1985. "The Death of the Long Poem", "Long-liners Conference”. Special issue. Open Letter 6, 2-3: 11-23. 
Mazoff, C. D. 1998. Anxious Allegiances. Legitimizing Identity in the Early Canadian Long Poem. Montreal: McGill-Queen's UP.

Nause, J. and M. Heenan. 1976. “An Interview with Louis Dudek”. Tamarack Review 68: $30-43$.

Ortiz, R. 1927. Fortuna Labilis. Storia di un motivo medievale. Bucarest: Cultura Nacionalâ.

Pound, E. 1928. Selected Poems. London: Faber \& Faber.

— 1968. Literary Essays. New York: New Directions.

— 1976. Collected Early Poems. New York: New Directions.

— 1993. The Cantos of Ezra Pound. New York: New Directions.

Quevedo, F. 1963. Obras completas. Poesía original. Barcelona: Planeta.

ReED, S. 1998. "The Place of American Poets in the Development of Irving Layton, Louis Dudek and Raymond Souster". Unedited doctoral thesis. University of Toronto.

Sherman, P. 1968. The Music of Survival: A Biography of a Poem by William Carlos Williams. Urbana: University of Illinois Press.

Schrier, L. 1990. "The Breathless Adventure. An Interview with Louis Dudek on the Long Poem”. Zymergy 4, 2: 39-53.

Smidt, G. 1993. "Rome From the French of Joachim Du Bellay. A European Perspective". Ezra Pound and Europe. Eds. R. Taylor and C. Melchor. Amsterdam: Rodopi.

Solecki, S. Al Purdy: The Last Canadian Poet. Toronto: Univ. Toronto Press, 1999.

Stromberg-Stein, S. 1983. Louis Dudek. A Biographical Introduction to his Poetry. Ottawa: Golden Dog Press.

Trenearne, B. 1999. The Montreal Forties: Modernist Poetry in Transition. Toronto: University of Toronto Press.

Wagner, L., ed. 1961. Interviews with William Carlos Williams. New York: A New Directions Book.

West, P. 1971. "Ethos and Epic: Aspects of Contemporary Canadian Poetry”. Contexts of Canadian Criticism. Ed. E. Mandel. Chicago: University of Chicago Press. 20615 .

Williams, W. C. 1958. I Wanted to Write a Poem. The Autobiography of the Works of a Poet. Boston: Beacon Press.

— 1988. The Collected Poems of William Carlos Williams. Volume II, 1939-1962. New York: New Directions.

Wilson, M. 1971. "Recent Canadian Verse". Contexts of Canadian Criticism. Ed. E. Mandel. Chicago and London: U of Chicago P. 198-205. 